\title{
Removal and transformation of hexavalent chromium in sequencing batch reactor
}

\author{
Siew-Leng Loo, Kwok-Yii Leong and Poh-Eng Lim* \\ School of Chemical Sciences, Universiti Sains Malaysia, 11800 Penang, Malaysia
}

\begin{abstract}
The objectives of this study are to evaluate the efficiency of removal of hexavalent chromium $(\mathrm{Cr}(\mathrm{VI}))$ in a sequencing batch reactor (SBR) and to ascertain the fate of $\mathrm{Cr}(\mathrm{VI})$ in the treatment process. An SBR was operated with the FILL, REACT, SETTLE, DRAW and IDLE periods in the time ratio of 2:12:2:1.5:6.5 for a cycle time of $24 \mathrm{~h}$. The study was divided into 5 phases with the addition of $0.5,2.0,3.0$ and $5.0 \mathrm{mg} / \ell$ of $\mathrm{Cr}(\mathrm{VI})$ in Phases II, III, IV and V for a duration of 46, 75, 43 and 16 operational cycles, respectively. The $\mathrm{Cr}(\mathrm{VI})$ removal efficiencies for SBR were found to be $79.8,88.4$ and $99.8 \%$ in Phases III, IV and V, respectively. The results revealed that $\mathrm{Cr}(\mathrm{VI})$ removal efficiency improved with acclimated activated sludge. Determination of $\mathrm{Cr}$ in the suspended sludge showed that around $95 \%$ of the $\mathrm{Cr}$ species were $\mathrm{Cr}(\mathrm{III})$. Determination of $\mathrm{Cr}$ concentration profiles during the FILL and REACT periods showed that the predominant species was $\mathrm{Cr}(\mathrm{III})$ as $\mathrm{Cr}(\mathrm{VI})$ was bio-reduced. The proposed $\mathrm{Cr}(\mathrm{VI})$ removal mechanism involves bioreduction to $\mathrm{Cr}(\mathrm{III})$ which was subsequently precipitated and adsorbed by activated sludge. Precipitation rather than sorption is envisaged to be the main path of removal of $\mathrm{Cr}(\mathrm{III})$ from the solution.
\end{abstract}

Keywords: Sequencing batch reactor, hexavalent chromium, removal, transformation, mechanism

\section{Introduction}

Chromium species in the +3 and +6 oxidation states are more commonly found in the environment. $\mathrm{Cr}(\mathrm{VI})$ is widely used in industries such as electroplating, metal finishing, wood preservation and leather tanning. It exists as different forms of oxyanions depending on the $\mathrm{pH}$ of the solution. Under strongly acidic conditions $(\mathrm{pH}<1), \mathrm{Cr}(\mathrm{VI})$ exists as $\mathrm{Cr}_{2} \mathrm{O}_{7}{ }^{2-}$, whereas between $\mathrm{pH} 2$ and 6 it exists as $\mathrm{HCrO}_{4}^{-}$. Under neutral or alkaline conditions, $\mathrm{Cr}(\mathrm{VI})$ is present as $\mathrm{CrO}_{4}{ }^{2-}$ (Kimbrough et al., 1999). These compounds are highly toxic due to their strong oxidising nature. Owing to the toxicity, exposure to $\mathrm{Cr}(\mathrm{VI})$ presents an acute health risk and chronic exposure may lead to mutagenesis and carcinogenesis. In contrast, $\mathrm{Cr}(\mathrm{III})$ is much less toxic and is essential for mammals in trace quantities (Orozco et al., 2008).

Conventional methods of removing $\mathrm{Cr}(\mathrm{VI})$ include chemical reduction to $\mathrm{Cr}$ (III) followed by precipitation under alkaline conditions, removal by ion exchange, or adsorption by various materials (Kumar et al., 2007; Orozco et al., 2008). However, most of the conventional methods are costly and involve the generation of a large amount of secondary wastes which preclude an efficient and cost-effective technology in treating chromium-containing wastewater. Biological treatment methods such as the conventional activated sludge process and sequencing batch reactor (SBR) may be a better alternative due to their lower operational cost, steady performance and easy recovery of some valuable metals. Several researchers have shown that the activated sludge process is effective in treating chromium-containing wastewater (Imai and Golyna, 1990; Stasinakis et al., 2004;

\footnotetext{
* To whom all correspondence should be addressed.

䓝 +604 653-3550; fax: +604 657-4854; e-mail: pelim@usm.my

Received 7 April 2011; accepted in revised form 14 December 2011.
}

Chen and $\mathrm{Gu}, 2005)$. The SBR is a modified version of the activated sludge process which carries out functions of equalisation, treatment and sedimentation in the same reactor in a temporal rather than spatial sequence. It offers the advantages of better tolerance to shock load, good settleability, simplicity and ease in operation as well as compact lay out. Sirianuntapiboon and Hongsrisuwan (2007) have shown that SBR was effective in removing $\mathrm{Cu}$ and $\mathrm{Zn}$ in industrial and synthetic wastewaters.

Studies on $\mathrm{Cr}(\mathrm{VI})$ removal mechanisms using various biosorbents in batch systems under acidic conditions have been conducted (Reddad et al., 2003; Park et al., 2005a; Park et al., 2005b; Xu et al., 2007; Park et al., 2008; Wang et al., 2009). The mechanisms proposed by these researchers were similar and generally involve the adsorption of the anionic $\mathrm{Cr}(\mathrm{VI})$ on protonated adsorption sites, followed by the reduction to $\mathrm{Cr}$ (III) by electrons donated by adjacent functional groups. However, the removal mechanism of $\mathrm{Cr}(\mathrm{VI})$ in a bioreactor may be different due to the difference in $\mathrm{pH}$ which affects the surface charge of the biomass and the complexity of the solution chemistry. Several researchers have investigated the $\mathrm{Cr}(\mathrm{VI})$ removal mechanism in the activated sludge process (Imai and Gloyna, 1990; Stasinakis et al., 2004; Chen and Gu, 2005). Among them, Stasinakis et al. (2004) proposed a 2-step mechanism involving the bioreduction of $\mathrm{Cr}(\mathrm{VI})$ to $\mathrm{Cr}(\mathrm{III})$ and subsequent adsorption of $\mathrm{Cr}$ (III) onto suspended solids. A relatively small portion of $\mathrm{Cr}(\mathrm{III})(<14 \%)$ could be precipitated (Stasinakis et al., 2003). The conclusion was drawn solely based on the findings from the speciation study conducted on the suspended solids and the effluent, but the transformation undergone by $\mathrm{Cr}(\mathrm{VI})$ during the treatment process was not discussed. In light of the above observations, the objectives of this study are: (i) to evaluate the removal efficiency of Cr(VI) in SBR under relatively low $\mathrm{Cr}(\mathrm{VI})$ loading rates and (ii) to ascertain the fate of $\mathrm{Cr}(\mathrm{VI})$ in the treatment process. 


\section{Experimental}

\section{Experimental set-up and operation}

A plexiglass reactor with dimensions of 19.5 x $25 \times 20 \mathrm{~cm}$ (width $x$ length $x$ height) and a working volume of $10 \ell$ was operated on a 24-h cycle with the FILL, REACT, SETTLE, DRAW and IDLE periods in the time ratio of 2:12:2:1.5:6.5. Mixing was provided during the FILL period by using an ejector. During each cycle, $7 \ell$ of influent and treated effluent were introduced and drawn, respectively. The sludge age was controlled at around 10 days. The base mix for the reactor was of the following composition (concentration in $\mathrm{mg} / \ell$ ): bactopeptone (188), sucrose (563), $\mathrm{KH}_{2} \mathrm{PO}_{4}(35), \mathrm{K}_{2} \mathrm{HPO}_{4}(180),\left(\mathrm{NH}_{4}\right)_{2} \mathrm{SO}_{4}(226), \mathrm{NaHCO}_{3}(576)$, $\mathrm{MgSO}_{4}$ (49), $\mathrm{FeCl}_{3} \cdot 6 \mathrm{H}_{2} \mathrm{O}$ (10), $\mathrm{CaCl}_{2}$ (42). The seed sludge for the reactor was obtained from a local municipal wastewater treatment plant. Ethanol solution $(\approx 4.6 \% \mathrm{v} / \mathrm{v})$ with a theoretical COD of $75.8 \mathrm{mg} \mathrm{O} / \mathrm{m} \ell$ was added as a carbon source on the commencement of the anoxic period. The study was divided into 5 phases. In Phase I, the reactor was operated without the addition of $\mathrm{Cr}(\mathrm{VI})$ for a period of 60 operational cycles. The reactor was then loaded with $0.5,2,3$ and $5 \mathrm{mg} / \ell$ of $\mathrm{Cr}(\mathrm{VI})$ during the FILL period in Phases II, III, IV and V, respectively, for a duration of $46,75,43$ and 16 operational cycles, respectively.

\section{Determination of performance parameters}

The mixed liquor suspended solids (MLSS) concentration and sludge volume index (SVI) were determined regularly in every phase following the Standard Methods (APHA, 1998). The $\mathrm{Cr}(\mathrm{VI})$ removal efficiency was evaluated by determining the concentrations of $\mathrm{Cr}(\mathrm{VI})$ and total $\mathrm{Cr}$ in the effluent for every operational cycle. Wasted sludge for every operational cycle was obtained to determine the concentration of total $\mathrm{Cr}$ accumulated in the sludge. During each phase, concentration profiles of $\mathrm{Cr}(\mathrm{VI}), \mathrm{Cr}(\mathrm{III})$ and total $\mathrm{Cr}$ in the aqueous and particulate phases during the FILL and REACT periods were determined. Mixed liquor samples were obtained from the reactor at a predetermined time interval and separated into the aqueous and particulate phases via filtration. The dissolved oxygen (DO) concentration and $\mathrm{pH}$ profiles were determined in situ by using a DO meter (YSI 550A) and a pH meter (Cyber Scan 500), respectively.

Total $\mathrm{Cr}$ and $\mathrm{Cr}(\mathrm{VI})$ concentrations in the aqueous phase were determined following Method No. 3111 B/3113 B and Method No. 3500-Cr B, respectively (APHA, 1998). Total Cr concentration was analysed by direct analysis of the filtrate using a flame atomic absorption spectrophotometer (FAAS) (Perkin Elmer AAS 3100) or a graphite furnace-AAS (Perkin Elmer Analyst 100), depending on the concentration ranges, while $\mathrm{Cr}(\mathrm{VI})$ was measured colourimetrically using an UV-Vis spectrophotometer (Hitachi U-2000). The Cr(VI) concentration in the suspended solids was determined by the selective leaching of $\mathrm{Cr}(\mathrm{VI})$ using sodium carbonate followed by final detection by graphite furnace-AAS (Perkin Elmer Analyst 100) as described in Elci et al. (2010). Total $\mathrm{Cr}$ concentration in the suspended sludge was determined by open digestion with concentrated nitric acid followed by FAAS analysis (APHA, 1998). For the aqueous and solid phases, $\mathrm{Cr}$ (III) concentrations were calculated from the difference between the total $\mathrm{Cr}$ and $\mathrm{Cr}(\mathrm{VI})$ concentrations.

\section{FTIR analysis}

Samples of the suspended sludge before and after exposure to different concentrations of $\mathrm{Cr}(\mathrm{VI})$ were obtained and dried in

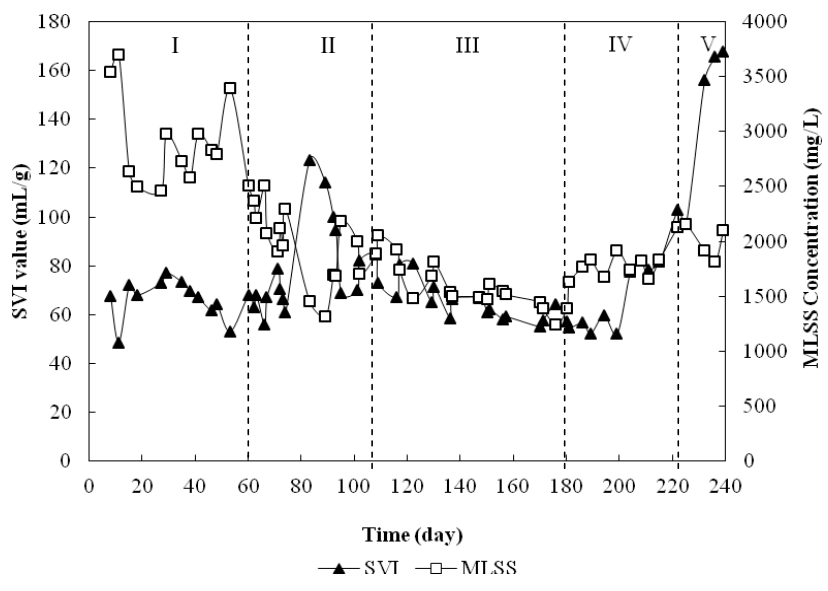

Figure 1

Trends of MLSS concentrations and SVI values during the operational period

the oven (Memmert 400$)$ at $105^{\circ} \mathrm{C}$. A minute amount of dried sludge was ground with dried $\mathrm{KBr}$ into fine particles by using mortar and pestle. The mixture was made into a translucent disk by compressing the mixture in a die using a manual hydraulic press. The resultant $\mathrm{KBr}$ disk was analysed using a FTIR spectrophotometer (Perkin Elmer 2000).

\section{Adsorption studies}

Equilibrium adsorption studies were conducted to determine the adsorption capacity of the suspended activated sludge for $\mathrm{Cr}(\mathrm{VI})$ and $\mathrm{Cr}(\mathrm{III})$ at $\mathrm{pH} 6,7$ and 8. Dried activated sludge of $0.100 \mathrm{~g}$ in weight and $<1 \mathrm{~mm}$ in size was shaken at $250 \mathrm{r}$ / min with $20.0 \mathrm{~m} \ell$ of $\mathrm{Cr}(\mathrm{VI})$ and $\mathrm{Cr}(\mathrm{III})$ solutions of concentrations ranging from 1.0 to $10.0 \mathrm{mg} / \ell$, for a duration based on the preliminary contact time study. After shaking, the sample was filtered and the filtrate was analysed for $\mathrm{Cr}(\mathrm{VI})$ and $\mathrm{Cr}(\mathrm{III})$ concentrations using the analytical methods described in the previous section. The point of zero charge $\left(\mathrm{pH}_{\mathrm{pzc}}\right)$ of the activated sludge was also determined (Ofomaja et al., 2009).

\section{Results and discussion}

\section{MLSS concentrations and SVI values}

The trends of MLSS concentrations and SVI values of the suspended sludge during the operational period are shown in Fig. 1. The decrease in MLSS concentration in Phase I (before $\mathrm{Cr}(\mathrm{VI})$ addition) was primarily due to sludge age control. At the beginning of Phase II, the MLSS concentration decreased drastically with the addition of $0.5 \mathrm{mg} / \ell$ of $\mathrm{Cr}(\mathrm{VI})$ due to the inhibitory effects of $\mathrm{Cr}(\mathrm{VI})$ on the growth of the biomass. Once the biomass had been acclimated to $\mathrm{Cr}(\mathrm{VI})$, the MLSS concentration increased, even at higher Cr(VI) dosages, in Phases IV and V. These results agree with those of Yetis et al. (1999), who reported that $\mathrm{Cr}(\mathrm{VI})$ exerted stimulatory effects on biomass yield up to $25 \mathrm{mg} / \ell$ of $\mathrm{Cr}(\mathrm{VI})$ in a continuous activated sludge system with acclimated cultures.

Figure 1 shows that the SVI values effectively varied between the values of 60 to $100 \mathrm{~m} \ell / \mathrm{g}$ throughout Phases I, II, III and IV, which is indicative of good settleability and compressibility (Fig. 1). However, the SVI values increased drastically in Phase $\mathrm{V}$ indicating that the sludge had yet to be acclimated to higher $\mathrm{Cr}(\mathrm{VI})$ concentrations in this phase, which was of relatively short duration. 

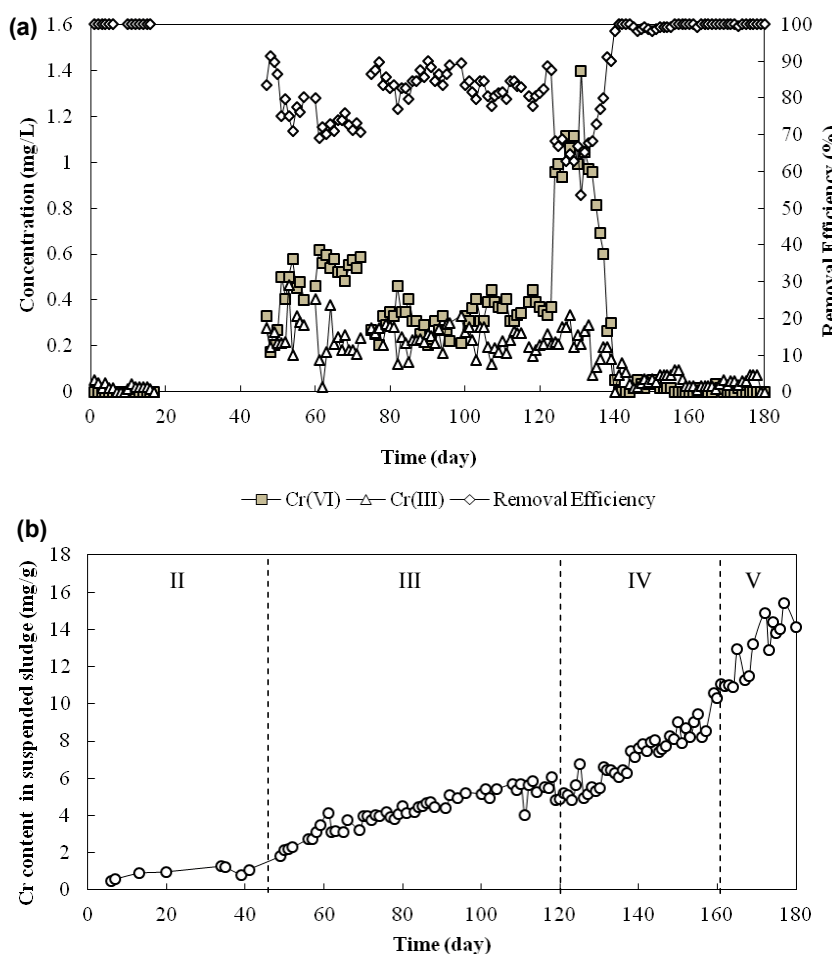

Figure 2

(a) Effluent $\mathrm{Cr}(\mathrm{III})$ and $\mathrm{Cr}$ (VI) concentrations and $\mathrm{Cr}(\mathrm{VII})$ removal efficiency and (b) total Cr concentration in the sludge during the operational period

\section{Cr removal}

The $\mathrm{Cr}(\mathrm{VI})$ removal efficiency was determined by monitoring the concentration of $\mathrm{Cr}(\mathrm{VI})$ in the effluent. Figure 2a depicts the effluent $\mathrm{Cr}(\mathrm{III})$ and $\mathrm{Cr}(\mathrm{VI})$ concentrations and the $\mathrm{Cr}(\mathrm{VI})$ removal efficiencies in the SBR. During Phase II, the reactor was very efficient in $\mathrm{Cr}(\mathrm{VI})$ removal as practically no $\mathrm{Cr}(\mathrm{VI})$ was detected in the effluent. When the influent $\mathrm{Cr}(\mathrm{VI})$ was increased to $2.0 \mathrm{mg} / \ell$ in Phase III, the mean removal efficiency decreased briefly but recovered quickly to $80 \pm 6 \%$. A similar trend was observed in Phase IV in which an increase of $\mathrm{Cr}(\mathrm{VI})$ to $3.0 \mathrm{mg} / \ell$ resulted in a drastic decrease in the removal efficiency for a brief period before recovering to more than $99 \%$. In Phase V, the removal efficiency remained above $99 \%$ despite an increase of $\mathrm{Cr}(\mathrm{VI})$ to $5.0 \mathrm{mg} / \ell$. The recovery in removal efficiency may be attributed to biomass acclimation to $\mathrm{Cr}(\mathrm{VI})$ containing feed. Chen and $\mathrm{Gu}$ (2005) also found that acclimated activated sludge had a higher $\mathrm{Cr}(\mathrm{VI})$ removal efficiency.

In comparison to other treatment systems, the SBR in this study was able to achieve a relatively high $\mathrm{Cr}(\mathrm{VI})$ removal efficiency. In comparison, Imai and Gloyna (1990) reported that the $\mathrm{Cr}(\mathrm{VI})$ removal efficiency for an aerated fed-batch activated sludge reactor operated at $\mathrm{pH} 7$ and 8 was less than $25 \%$. Stasinakis et al. (2004) reported a mean $\mathrm{Cr}(\mathrm{VI})$ removal of $42 \pm 11 \%$ using an aerobic activated sludge system. The higher $\mathrm{Cr}(\mathrm{VI})$ removal efficiency achieved in this study might be due to the employment of agitated FILL period without aeration. At such a low-DO environment, the reduction of $\mathrm{Cr}(\mathrm{VI})$ to $\mathrm{Cr}(\mathrm{III})$ was highly favourable thereby decreasing the concentration of $\mathrm{Cr}(\mathrm{VI})$. Stasinakis et al. (2004) studied the effect of aerobic and anoxic reactors in the reduction of $\mathrm{Cr}(\mathrm{VI})$ and found that the inclusion of an anoxic reactor prior to the aerobic reactor had improved the mean $\mathrm{Cr}(\mathrm{VI})$ removal to $84 \pm 9 \%$ when the influent $\mathrm{Cr}(\mathrm{VI})$ concentration was at $1 \mathrm{mg} / \ell$.

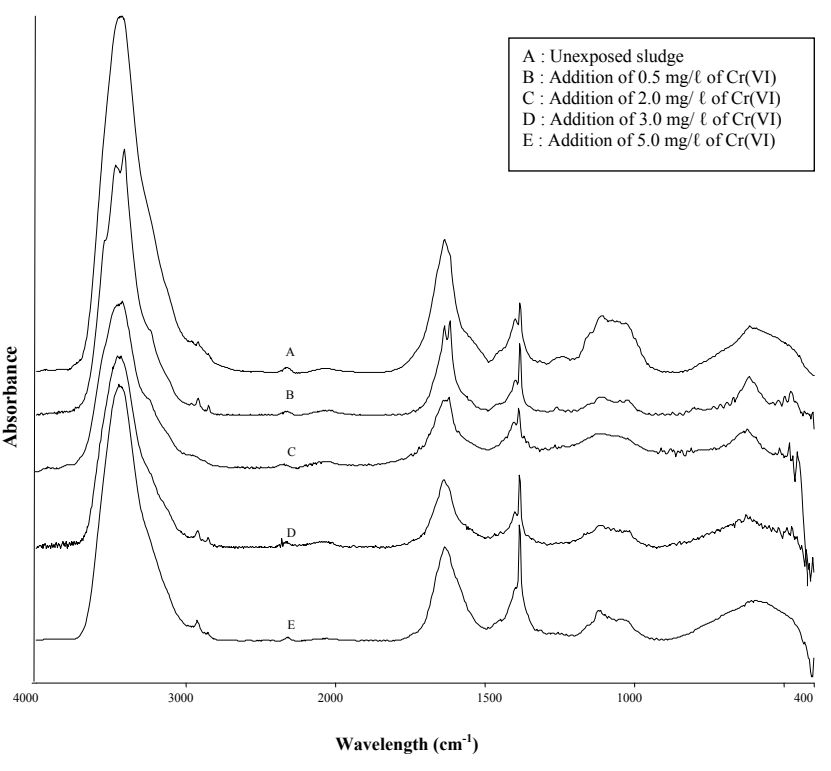

Figure 3

FTIR spectra of activated sludge before and after Cr(VI) addition

Since $\mathrm{Cr}$ introduced into the reactor was almost completely removed during most phases, the removed $\mathrm{Cr}$ species should be accumulated in the sludge. Therefore, samples of suspended sludge for each operational cycle were obtained for the determination of total Cr. Suspended sludge samples collected in Phases IV and V were also analysed for the content of $\mathrm{Cr}$ species and it was found that $\mathrm{Cr}$ (III) constituted $95 \pm 1 \%$ of $\mathrm{Cr}$ in the sludge. Figure $2 \mathrm{~b}$ depicts the trend of total $\mathrm{Cr}$ concentrations in the suspended sludge with the operational period, which showed a general increase of $\mathrm{Cr}$ content in the sludge with time. The $\mathrm{Cr}$ species removed from the bulk solution could accumulate in the suspended sludge through processes such as adsorption, precipitation and intracellular uptake of $\mathrm{Cr}$ species by living cells (Imai and Golyna, 1996). The rates of increase in the Cr content in Phases II, III, IV and V were estimated to be $0.015,0.044,0.136$ and $0.199 \mathrm{mg} / \mathrm{g}$ per day, respectively, based on a linear fit to the data for each phase shown in Fig. 2b. The higher rate of increase in Phases IV and V was attributed to the higher concentrations of $\mathrm{Cr}(\mathrm{VI})$ being added and higher $\mathrm{Cr}(\mathrm{VI})$ removal efficiencies.

\section{FTIR analysis}

The adsorption sites on the activated sludge surface can be identified by analysing the FTIR spectra of the sludge before and after Cr(VI) addition (Fig. 3). The FTIR spectrum of the unexposed sludge displayed a broad absorption peak at 3430 $\mathrm{cm}^{-1}$ which may be assigned to the presence of $-\mathrm{O}-\mathrm{H}$ and $-\mathrm{N}-\mathrm{H}$ functionalities. The peaks at 1637 and $1385 \mathrm{~cm}^{-1}$ were probably due to the $\mathrm{C}=\mathrm{O}$ and the $\mathrm{C}-\mathrm{O}$ stretching of carboxylate group. A shoulder at $1107 \mathrm{~cm}^{-1}$ could be assigned to cellulosic $-\mathrm{O}-\mathrm{H}$. The high functionalities of the activated sludge indicate that adsorption may occur through surface complexation in addition to electrostatic attraction and ion exchange mechanisms. Two changes were observed in the FTIR spectra of the sludge after $\mathrm{Cr}(\mathrm{VI})$ addition. The first change was the weaker appearance of the shoulder at $1107 \mathrm{~cm}^{-1}$ indicating the involvement of cellulosic $-\mathrm{O}-\mathrm{H}$ in sequestering $\mathrm{Cr}$ (III) and to a lesser extent $\mathrm{Cr}(\mathrm{VI})$. This showed that extracellular polymer (EP) produced by the activated sludge played a role in the adsorption 


\begin{tabular}{|c|c|c|c|c|}
\hline $\begin{array}{r}\text { Ratios of } \mathrm{tr} \\
\text { and } 1\end{array}$ & $\begin{array}{r}\text { Table } 1 \\
\text { peak heights of ab } \\
637 \mathrm{~cm}^{-1} \text { for activate }\end{array}$ & $\begin{array}{l}\text { orption } \\
\text { sludg }\end{array}$ & $\begin{array}{l}\text { bands } \\
\text { sampl }\end{array}$ & 385 \\
\hline Activated & Initial $\mathrm{Cr}(\mathrm{VI})$ concen- & Absor & ance & $A_{1385} I$ \\
\hline mple & tratio & $A_{1385}$ & $A_{1637}$ & $A_{1637}^{1000}$ \\
\hline Unexposed & - & 0.0181 & 0.0374 & 0.4840 \\
\hline Exposed & 0.5 & 0.0207 & 0.0271 & 0.7638 \\
\hline Exposed & 2.0 & 0.0182 & 0.0163 & 1.1165 \\
\hline Exposed & 3.0 & 0.0210 & 0.0181 & 1.1602 \\
\hline Exposed & 5.0 & 0.0321 & 0.0253 & 1.2688 \\
\hline
\end{tabular}

process because its main composition is polysaccharide (Brown and Lester,1979). The disappearance of the cellulosic $-\mathrm{O}-\mathrm{H}$ after the adsorption of Cd by EP was also observed by Zheng et al. (2008). The second change in the FTIR spectra of the sludge after $\mathrm{Cr}(\mathrm{VI})$ addition was the relative height of the peaks at 1637 and $1385 \mathrm{~cm}^{-1}$. The maximum peak height of the 2 peaks was obtained by using a spectral calculator. Table 1 shows that the ratio of the peak height of adsorption due to $\mathrm{C}-\mathrm{O}$ stretching to that of adsorption due to $\mathrm{C}=\mathrm{O}$ stretching increased with initial Cr(VI) concentration. Pagnanelli et al. (2009) also observed a shift in the relative intensities of the carboxylate peaks at 1621 and $1418 \mathrm{~cm}^{-1}$, indicative of interaction between metal ions with carboxylic adsorbent sites.

\section{Equilibrium adsorption studies}

The adsorption data were fitted to the Freundlich and Langmuir models to determine the adsorption capacities of the dried suspended sludge for $\mathrm{Cr}(\mathrm{VI})$ and $\mathrm{Cr}(\mathrm{III})$. The linearised Freundlich and Langmuir isotherms are expressed, respectively, by the following equations:

$$
\begin{aligned}
& \log Q_{e}=\log K_{F}+(1 / n) \log C_{e} \\
& \text { and } C_{e} / Q_{e}=\left(1 / K_{L} Q_{M}\right)+C_{e} / Q_{M}
\end{aligned}
$$

where:

$Q_{e}$ is the amount of $\mathrm{Cr}$ adsorbed per unit mass of the adsorbent at equilibrium $(\mathrm{mg} / \mathrm{g})$,

$K_{F}$ is a constant related to the adsorption capacity of the adsorbent,

$n$ is a constant related to the affinity of the activated sludge for $\mathrm{Cr}$,

$C_{e}$ is the residual concentration of $\mathrm{Cr}$ in the dissolved phase after adsorption $(\mathrm{mg} / \ell)$,

$Q_{M}$ is the maximum adsorption capacity $(\mathrm{mg} / \mathrm{g})$ and

$K_{L}$ is a constant related to the affinity of adsorption $(\ell / \mathrm{mg})$.

The Freundlich and Langmuir parameters are shown in Table 2.
The Freundlich model adequately described $\left(R^{2}>0.87\right)$ the adsorption data for $\mathrm{Cr}(\mathrm{VI})$ and $\mathrm{Cr}(\mathrm{III})$. However, the $\mathrm{Cr}(\mathrm{III})$ adsorption data could not fit the Langmuir model. The $K_{F}$ values for $\mathrm{Cr}(\mathrm{III})$ were higher than those of $\mathrm{Cr}(\mathrm{VI})$ indicating that the sludge had a higher adsorption capacity for $\mathrm{Cr}(\mathrm{III})$. Table 2 shows a decreasing $Q_{M}$ value for $\operatorname{Cr}(\mathrm{VI})$ adsorption with the increase in $\mathrm{pH}$ from 6 to 8 . The $\mathrm{pH}_{\mathrm{pzc}}$ of the sludge was found to be 6.4 indicating that the net surface charge of the sludge was negative at $\mathrm{pH}$ values above 6.4 . Thus, the electrostatic repulsion between the anionic $\mathrm{Cr}(\mathrm{VI})$ species and the negative surface charge of the sludge resulted in a relatively lower adsorption of $\mathrm{Cr}(\mathrm{VI})$ at higher $\mathrm{pH}$ values. This finding suggests that the accumulation of total $\mathrm{Cr}$ in the suspended sludge may in part be due to the adsorption of $\mathrm{Cr}(\mathrm{III})$ rather than $\mathrm{Cr}(\mathrm{VI})$.

\section{Transformation of $\mathrm{Cr}(\mathrm{VI})$ during the FILL and REACT periods in SBR}

Figure 4a-c shows the concentration profiles of $\mathrm{Cr}(\mathrm{III}), \mathrm{Cr}(\mathrm{VI})$ and DO during the FILL and REACT periods on the $73^{\text {rd }}, 43^{\text {rd }}$ and $14^{\text {th }}$ cycles in Phases III, IV and V, respectively. The $\mathrm{pH}$ of the reactor varied between $\mathrm{pH} 7$ and 8 . Figure 4a shows a build-up of $\mathrm{Cr}(\mathrm{VI})$ and relatively low $\mathrm{Cr}$ (III) concentrations during the FILL period in Phase III. This could be explained by the fact that acclimation had not yet been achieved. It was also observed that $\mathrm{Cr}(\mathrm{VI})$ removal during the anoxic REACT period was faster than the aerobic REACT period. The addition of ethanol solution into the reactor at the beginning of the anoxic period could have aided the reduction of $\mathrm{Cr}(\mathrm{VI})$ by acting as an electron donor. It has been shown that $\mathrm{Cr}(\mathrm{VI})$ reduction efficiency is dependent on the organic substrate concentration (Stasinakis et al., 2003). In Phase IV, there was more Cr(III) than $\mathrm{Cr}(\mathrm{VI})$ found during the FILL period (Fig. $4 \mathrm{~b}$ ) and in Phase V, a near-complete removal of $\mathrm{Cr}(\mathrm{VI})$ accompanied by a build-up of $\mathrm{Cr}$ (III) was observed. This result indicates that the activated sludge was acclimated to $\mathrm{Cr}(\mathrm{VI})$ and most of the $\mathrm{Cr}(\mathrm{VI})$ removed was reduced to $\mathrm{Cr}(\mathrm{III})$.

Figure $4 \mathrm{c}$ also provides the evidence that the removal of $\mathrm{Cr}(\mathrm{VI})$ via reduction to $\mathrm{Cr}$ (III) during the FILL period mainly occurred in the aqueous phase as intracellular reduction of $\mathrm{Cr}(\mathrm{VI})$ would be unlikely due to electrostatic repulsion between the net negative surface charge on the sludge at the operating $\mathrm{pH}$ range of 7-8 in the reactor and the anionic $\mathrm{Cr}(\mathrm{VI})$. The hypothesis is also supported by the observation of a relatively high $\mathrm{Cr}$ (III) concentration in the solution during the FILL period. If $\mathrm{Cr}(\mathrm{VI})$ reduction were to take place on the sludge, the resulting $\mathrm{Cr}$ (III) species would not be released easily to the solution as it would be attracted to the negatively-charged acti-

\begin{tabular}{|c|c|c|c|c|c|c|c|}
\hline \multicolumn{8}{|c|}{\begin{tabular}{|c} 
Table 2 \\
Freundlich and Langmuir parameters for the adsorption of $\mathrm{Cr}(\mathrm{VII})$ and $\mathrm{Cr}(\mathrm{III})$ \\
by dried activated sludge
\end{tabular}} \\
\hline \multirow[t]{2}{*}{$\mathrm{Cr}$} & \multirow[t]{2}{*}{$\mathrm{pH}$} & \multicolumn{3}{|c|}{ Freundlich parameter } & \multicolumn{3}{|c|}{ Langmuir parameter } \\
\hline & & $K_{F}$ & $n$ & $R^{2}$ & $\begin{array}{c}Q_{\max } \\
(m g / g)\end{array}$ & $\begin{array}{c}K_{L} \\
(\ell / \mathrm{mg})\end{array}$ & $R^{2}$ \\
\hline \multirow{3}{*}{ III } & 6 & $0.92 \pm 0.33$ & $1.3 \pm 0.4$ & 0.910 & & & \\
\hline & 7 & $1.04 \pm 0.18$ & $0.9 \pm 0.1$ & 0.986 & & & \\
\hline & 8 & $1.56 \pm 1.11$ & $0.8 \pm 0.3$ & 0.875 & & & \\
\hline \multirow{3}{*}{ VI } & 6 & $0.56 \pm 0.20$ & $3.5 \pm 1.7$ & 0.966 & $1.05 \pm 0.04$ & $2.03 \pm 1.67$ & 0.921 \\
\hline & 7 & $0.58 \pm 0.22$ & $4.6 \pm 0.6$ & 0.933 & $0.82 \pm 0.28$ & $3.54 \pm 0.60$ & 0.994 \\
\hline & 8 & $0.48 \pm 0.14$ & $4.9 \pm 2.0$ & 0.874 & $0.69 \pm 0.10$ & $4.35 \pm 1.83$ & 0.982 \\
\hline
\end{tabular}
vated sludge. The relatively high $\mathrm{Cr}$ (III) concentration that was 

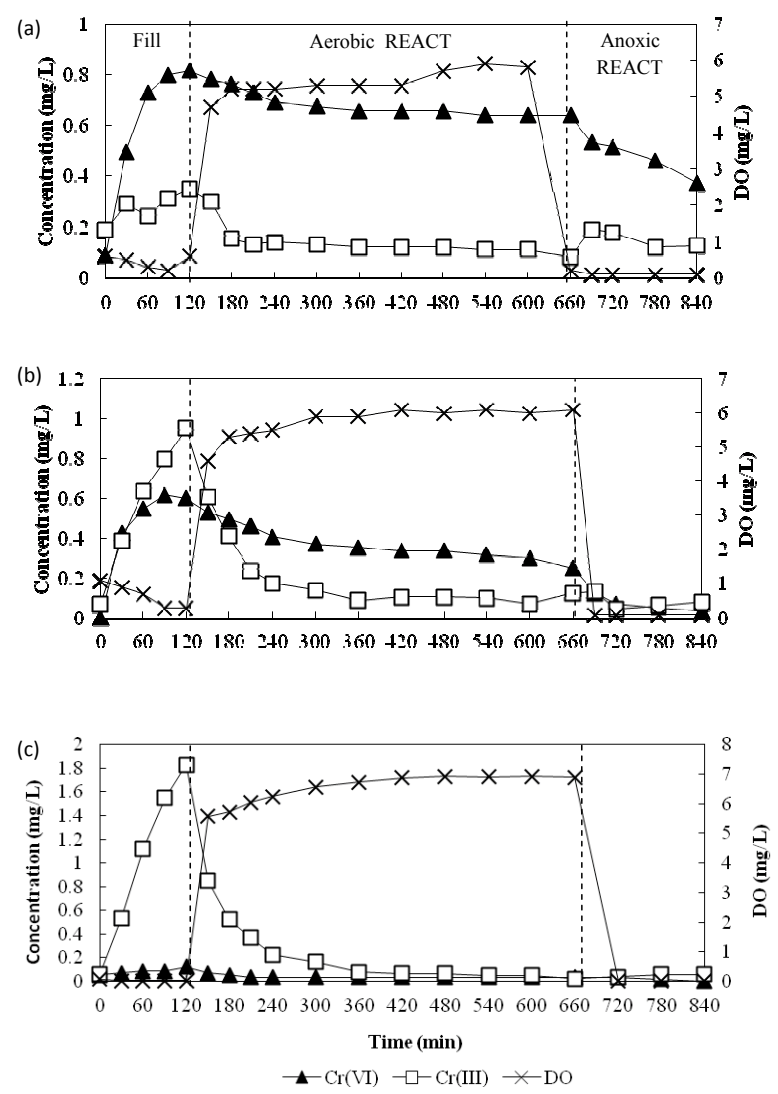

Figure 4

Concentration profiles of $\mathrm{Cr}(I I I), \mathrm{Cr}(\mathrm{VI})$ and $\mathrm{DO}$ in SBR during the FILL and REACT periods in phases (a) III, (b) IV and (c) V

not removed during the FILL period in Phases IV and V might be due to complexation with the added organic substrates. It has been shown that metal precipitation ceased with increasing organic concentration (Remoundaki et al., 2007).

$\mathrm{Cr}$ (III) was observed to be removed from the solution very rapidly at the beginning of the aerobic REACT period in Phases IV and V (Fig. 4b and 4c). Precipitation is envisaged to be the main path of removal as the adsorption capacity of the biomass for $\mathrm{Cr}(\mathrm{III})$ has long been fulfilled at this stage. Steritt et al. (1981) found that the main $\mathrm{Cr}$ (III) removal mechanism in an activated sludge system operated at $\mathrm{pH}$ 7.4-7.7 was precipitation. The enhanced precipitation of Cr(III) upon the start of the aerobic REACT period in Phases IV and V may be the result of a combination of several factors including (i) increase in the $\mathrm{pH}$ of the mixed liquor, (ii) decreasing organic content due to microbial metabolism of organics in the presence of $\mathrm{O}_{2}$ and (iii) high $\mathrm{Cr}(\mathrm{III})$ concentration which had exceeded the solubility product of $\mathrm{Cr}(\mathrm{OH})_{3}$. The precipitated $\mathrm{Cr}(\mathrm{III})$ may then be physically entrapped in the activated sludge flocs or it may settle independently from the solution forming a part of the sludge. Oxidation of $\mathrm{Cr}$ (III) to $\mathrm{Cr}(\mathrm{VI})$ was not observed during the aerobic REACT period even when the dissolved oxygen concentration was relatively high (Fig. $4 \mathrm{~b}-\mathrm{c}$ ). This can be explained by the relatively slow rate of $\mathrm{Cr}$ (III) oxidation as compared to sorption and precipitation (Schroeder and Lee, 1975).

\section{Conclusions}

The $\mathrm{Cr}(\mathrm{VI})$ removal efficiencies for SBR were found to be 80 , 89 and more than $99 \%$ when the influent $\mathrm{Cr}(\mathrm{VI})$ concentrations were 2,3 and $5 \mathrm{mg} / \ell$ (loading rates of $1.4 \times 10^{-3}, 2.1 \times 10^{-3}$, $3.5 \times 10^{-3} \mathrm{~kg} / \mathrm{m}^{3}$ day), respectively. The results revealed that $\mathrm{Cr}(\mathrm{VI})$ removal efficiency improved with acclimated activated sludge The adsorption data of $\mathrm{Cr}(\mathrm{VI})$ and $\mathrm{Cr}$ (III) fitted the Freundlich model fairly well. The adsorption study showed that the activated sludge had a relatively higher adsorption capacity for $\mathrm{Cr}(\mathrm{III})$ than for $\mathrm{Cr}(\mathrm{VI})$. The adsorption sites were identified as the carboxyl and cellulosic alcohol groups via the FTIR analysis. Determination of $\mathrm{Cr}$ in the suspended sludge showed that most of the Cr species were Cr(III). Determination of the Cr concentration profiles during the FILL and REACT periods showed that $\mathrm{Cr}$ (III) was the dominant species in the solution. Precipitation is envisaged to be the main path of removal for $\mathrm{Cr}(\mathrm{III})$.

\section{References}

APHA (1998) Standard Methods for the Examination of Water and Wastewater $\left(20^{\text {th }}\right.$ edn.). American Public Health Association, Washington, DC.

BROWN MJ and LESTER JN (1979) Metal removal in activated sludge: The role of bacterial extracellular polymers. Water Res. 13 817-837.

CHEN Y and GU G (2005) Preliminary studies on continuous chromium(VI) biological removal from wastewater by anaerobicaerobic activated sludge process. Bioresour. Technol. 96 1713-1721.

ELCI L, DIVRIKLI U, AKDOGAN A, HOL A, CETIN A and SOYLAK M (2010) Selective extraction of chromium(VI) using a leaching procedure with sodium carbonate from some plant leaves, soil and sediment samples. J. Hazard. Mater. 173 778-782.

IMAI A and GOLYNA EF (1990) Effects of $\mathrm{pH}$ and the oxidation state of chromium on the behaviour of chromium in the activated sludge process. Water Res. 24 1143-1150.

IMAI A and GOLYNA EF (1996) Speciation of chromium(III) in activated sludge. Water Environ. Res. 68 301-310.

KIMBROUGH DE, COHEN Y, WINER AM, CREELMAN L and MABUNI C (1999) A critical assessment of chromium in the environment. Crit. Rev. Env. Sci. Technol. 29 1-46.

KUMAR PA, RAY M and CHAKRABORTY S (2007) Hexavalent chromium removal from wastewater using aniline formaldehyde condensate coated silica gel. J. Hazard. Mater. 143 24-32.

OFOMAJA AE, NAIDOO EB and MODISE SJ (2009) Removal of copper(II) from aqueous solution by pine and base modified pine cone powder as biosorbent. J. Hazard. Mater. 168 909-917.

OROZCO AMF, CONTRERAS EM and ZARITZKY NE (2008) Modelling $\mathrm{Cr}(\mathrm{VI})$ removal by a combined carbon-activated sludge system. J. Hazard. Mater. 150 46-52.

PAGNANELLI F, MAINELLI S, BORNORONI L, DIONISI D and TORO L (2009) Mechanisms of heavy-metal removal by activated sludge. Chemosphere 75 1028-1034.

PARK D, YUN YS, JO JH and PARK JM (2005a) Mechanism of hexavalent chromium removal by dead fungal biomass of Aspergillus niger. Water Res. 39 533-540.

PARK D, YUN YS and PARK JM (2005b) Studies on hexavalent chromium biosorption by chemically-treated biomass of Ecklonia sp. Chemosphere 60 1356-1364.

PARK D, YUN YS, LEE HW and PARK JM (2008) Advanced kinetic model of the $\mathrm{Cr}(\mathrm{VI})$ removal by biomaterials at various $\mathrm{pHs}$ and temperatures. Bioresour. Technol. 99 1141-1147.

REDDAD Z, GERENTE C, ANDRES Y and LE CLOIREC P (2003) Mechanism of $\mathrm{Cr}$ (III) and $\mathrm{Cr}(\mathrm{VI})$ removal from aqueous solutions by sugar beet pulp. Environ. Technol. 24 257-264.

REMOUNDAKI E, HATZIKIOSEYIAN A and TSEZOS M (2007) A systematic study of chromium solubility in the presence of organic matter: consequences for the treatment of chromium-containing wastewater. J. Chem. Technol. Biotechnol. 82 802-808.

SCHROEDER DC and LEE GF (1975) Potential transformations of chromium in natural waters. Water Air Soil Pollut. 4 355-365.

SIRIANUNTAPIBOON S and HONGSRISUWAN T (2007) Removal of $\mathrm{Zn}^{2+}$ and $\mathrm{Cu}^{2+}$ by a sequencing batch reactor. Bioresour. Technol. 98 808-818. 
STASINAKIS AS, THOMAIDIS NS, MAMAIS D, KARIVALI M and LEKKAS TD (2003) Chromium species behavior in the activated sludge process. Chemosphere $\mathbf{5 2}$ 1059-1067.

STASINAKIS AS, THOMAIDIS NS, MAMAIS D and LEKKAS TD (2004) Investigation of $\mathrm{Cr}$ (VI) reduction in continuous-flow activated sludge systems. Chemosphere 57 1069-1077.

STERRITT RM, BROWN MJ and LESTER JN (1981) Metal removal by adsorption and precipitation in the activated sludge process. Environ. Pollut. Series A Ecol. Biol. A 24 313-323.

WANG XS, CHEN LF, LI FY, CHEN KL, WAN WY and TANG YJ (2009) Removal of Cr(VI) with wheat-residue derived from black carbon: Reaction mechanism and performance. J. Hazard. Mater. 175 816-822.

XU H, WONG YS, WONG MF and FUNG NYT (2007) Biosorption and bioreduction of $\mathrm{Cr}(\mathrm{VI})$ by a microalgal isolate, Chlorella miniata. J. Hazard. Mater. 146 65-72.

YETIS U, DEMIRER GN and GOKCAY CF (1999) Effect of chromium(VI) on the biomass yield of activated sludge. Enzyme Microb. Technol. 25 48-54.

ZHENG L, TIAN Y, DING AZ and WANG JS (2008) Adsorption of $\mathrm{Cd}(\mathrm{II}), \mathrm{Zn}(\mathrm{II})$ by extracellular substances extracted from waste activated sludge. Water Sci. Technol. 58 195-200. 